\title{
Adolescents' Gadget Addiction and Family Functioning
}

\author{
Annisa Maulidya Chasanah ${ }^{1 *}$, Grace Kilis ${ }^{2}$ \\ 1, 2. Faculty of Psychology, Universitas Indonesia, Depok, Indonesia \\ *E-mail: annisamaulidya.chasanah@gmail.com
}

\begin{abstract}
The aim of the study is to examine whether gadget addiction influences adolescent's family functioning and its dimensions. Data were collected from 226 adolescents aged 12-18 years old. We used Smartphone Addiction Scale Short Version (SAS-SV) developed by Kwon et al. (2013) to measure gadget addiction and Family Assessment Device (FAD) developed by Epstein et al. (1983) to measure family functioning. The results showed a negative effect of gadget addiction on family functioning $\left(\mathrm{F}(1,224)=30,796, p<0,001\right.$ (1-tailed), $\left.\mathrm{R}^{2}=0,121\right)$. Results from MANOVA statistics showed that there is significant differences of the six family functioning dimensions between adolescents with high and low-risk gadget addiction $(\mathrm{F}(7,218)=4,852$, $\mathrm{p}<0,01$ (1-tailed); Wilks' $\Lambda=0,865$, partial $\eta^{2}=0,135$ ), significant at $p=0,000-0,006$ ). Thus, we found the support that gadget addiction influences family functioning negatively and its implications are discussed.
\end{abstract}

Keywords: risk of gadget addiction; family functioning; gadget addiction; smartphone addiction scale; family assessment device

\section{Introduction}

In 2014, Millward Brown, a multinational company from England, published their research on screen time duration people spent on every day from 30 countries. Among those countries, Indonesia had the longest screen time duration, followed by Philippines and China. Based on the survey, the average use of electronic media per day in Indonesia reaches 540 minutes-equivalent to nine hours (Millward Brown, 2014). Out of the four electronic media mentioned by Millward Brown, smartphone and tablet are the most used media in Indonesia that take $54 \%$ of total screen time. The use of smartphones and tablets - will be called gadgets, is more on demand lately. The reason is that gadgets have high mobility so that people can use them anywhere and whenever they want. Not only that, its multifunctional features makes it easier to do many things.

Furthermore, survey results from Nielsen Company (2011), a global research company, mentioned that
$91 \%$ of Indonesian have a mobile phone. One of the advantages of gadgets developed lately is the ability to connect with internet which makes it easier to access various things in the world. Mobile phone can be used for a variety of purposes ranging from playing games, listening to music, watching videos, accessing information and social media via the internet. There are at least $21 \%$ of Indonesian who are active users of the internet. This percentage is quite large considering Indonesian's population which exceeds 237 million of people. Of these people, 55\% are teenagers ages 15-19; 26\% aged 20-29 years; and 19\% others aged 30 years and over.

Gadget use in teenagers is a common phenomenon. According to Wei and Lo (2006), there are at least six main reasons why individuals use gadgets. The six reasons are to seek information, social functionality, affection, style, mobility, and accessibility.

For adolescents, ability to easily connect with friends is an important key to why teenagers use 
gadgets since teens do a lot of exploring by spending more time with their friends than their parents in this developmental stage (Miller, 2011; Papalia \& Martorell, 2014). The presence of gadgets can connect teens to their friends more easily through social media and chat apps, as teenagers do not even need to directly face-to-face with their friends to communicate (Rothman, n.d.).

Although there are many positive impacts of gadgets that facilitate teenagers, excessive usage is always not a good thing. The excessive use of gadgets usually occurs because it is used as a means of entertainment, such as playing games, especially to boys. Girls mostly used gadget for social functions such as social media or chat (Slide, 2006). Based on the study conducted by Pew Research Centre (2015) on 1.060 teens aged13-17 years old, almost $92 \%$ of them goes online every day. Their parents found it difficult to monitor their online habits because they use more than one social media. It not only happens in America and other developed country, but also in Indonesia, as there is increasing use of mobile phones up to $89 \%$ (GSM Association, 2013). In early 2018, there were also reports that two students in Java were suspected to be addicted to smartphone and shows several acute symptoms of addiction (Sihombing, 2018).

Today generation adolescents (born from 1995 to the present) are often referred to as $\mathrm{Z}$ generations, millennials, internet generation, or digital natives (Törocsik, Szucs, \& Kehl, 2014). This generation tends to have some problems if they are separated to their gadgets in this era of globalization. They always want to get short, up-to-date, and having real-time information with picture attached Törocsik, Szucs, \& Kehl, 2014). This is supported by a research conducted by Moeller et al. (2010). They asked teenagers not to use their mobile phones and chat for 24 hours. The results showed that teenagers displayed excessive anxiety as well as showing dependence symptom of gadgets.

The difficulty to be comfortable in a situation with minimum access to the object of interest, anxious when the object is absent, excessive use and feeling dependent on the object are symptoms of addiction.
Addiction is any activity, substance, object, or behavior that is the primary focus in a person's life, which may prevent him/her from optimally performing other activities to the extent that it may harm the person or others physically, mentally or socially (Engs 1987). Based on the phenomenon of excessive gadgets use, gadgets could be the object of addiction for adolescents.

Gadget addiction has negative effects on teenage life, whether in health, academic, social, or family. Regarding health, Rosen et al. (2014) found that the use of technology such as gadgets can predict decreased physical activity, poor diet, and increased likelihood of obesity in adolescents. In academics, gadget addiction negatively affects academic achievement, because teens are more easily distracted in the classroom and when working on tasks if gadgets are present; and they have issues related to time management ability (Pierce \& Vaca, Srivastava, Hong et al. in Al-Barashdi, Bouazza, \& Jabur, 2015). In social life, excessive gadget use plays a role in the lack of face-to-face interaction, since teenagers are more likely to communicate using short messages through gadgets (Srivastava, 2005). Even the use of gadgets can also interfere with the quality of face-to-face interaction with others because many people keep using their gadgets when talking to others (Drago, 2015).

In 2013, Turkle viral the term of "together but alone", or "connected but alone". This term is often used since she published her book, "Alone Together", on how this era of technology shapes human relationships with others (May, 2013). This term describes how people spend more time with their gadgets compared to family or others even though they are meeting and gathering together. It referred to "together but alone", because although they are physically close to their family, they rarely spend quality time together as each of them are busy with gadgets. The use of gadgets among children and teenagers also makes parents worry because of the shortened time they can spend with their children (Villegas, 2013). Somehow, it seems natural for families to use gadgets when it is quality time with family, such as watching videos on 
gadgets when meal time (Fiese, Schwartz, \& Society for Research in Child in Villegas, 2013).

Based on the results of previous studies and phenomenon illustrated above, we are interested to further explore gadget use and its influence towards family functioning - especially among adolescents in Indonesia. We recognize that family is a party that plays a role in providing a sense of security for teenagers. If they have a family, the teenagers will feel safer to explore and know he can rely on family when in trouble (Papalia \& Martorell, 2014). Not only that, but the family also plays a role in controlling the behavior of its members and regulating attention, arousal, and emotional system. Through family, adolescents learn how to behave appropriately according to the culture and environment (Maughan, 2011). To develop optimally, adolescents need their family to fulfill their various functions, such as affective function, socialization and value transfer, health and fulfillment of life, reproductive, as well as economic needs (Lamanna \& Riedmann, 2005). However, these functions can only perform well if the process and dynamics that occur in the family are good. Processes and dynamics within the family where all members can thrive when facing the challenges of everyday life are referred to family functioning (Dai \& Wang, 2015).

As mentioned by Carvalho, Fonseca, Francisco, Bacigalupe, and Relvas (2016) in their metaanalysis study, there were some gaps in the previous studies, which are (1) inconsistency of the results obtained, (2) various types of media technologies used, (3) different family functioning variables, (4) the use of non-standardized measurements, and (5) variety of research methods used. These research gaps lead us to conduct a research that may provide more conclusive evidence. This study aimed to see the effect of gadget use addiction on adolescents' family functioning and its dimensions. To overcome previous studies' limitation, we used standardized measuring instruments and performed psychometric testing before, and use all of the variables in family functioning.
The research questions are as followed:

A. Do excessive gadget usage influence adolescents' family functioning?

B. Are there any differences in the dimensions of family functioning between adolescents that have a high and low risk of gadget use addiction?

\section{Smartphone Addiction}

Gadget addiction has several terms such as smartphone addiction, mobile phone addiction, problematic mobile phone use (PMPU), mobile phone dependence, compulsive mobile phone use, and mobile phone overuse (Al-Barashdi, Bouazza, \& Jabur, 2015). Gadget addiction is a maladaptive behavior of media usage with characteristics of excessive gadget use, difficulty to control and interference with daily activities (Kwan \& Leung, 2015; Kwon et al., 2013). Gadget addition is included in behavioral addiction.

\section{McMaster Model of Family Functioning}

Family functioning is a process of interaction that occurs among family members in order to meet their needs, duties, and other demands, while still emphasizing and guaranteeing the development and welfare of each members in all aspects (physical, emotional, and social aspects) (Epstein, Ryan, Bishop, Miller, and Keitner, 2003; Lanigan, 2009).

The McMaster Model of Family Functioning (MMFF) is a family functioning model composed by Epstein, Bishop and Levin (1978). This model sees the family as a social system where a family is not only seen from its individuals, but also the interactions that occur among individuals in the family. As a system, family members can influence and control each other's behavior using several rules. The basic assumptions of this model are (Miller, Ryan, Keitner, Bishop, \& Epstein, 2000):

1. All members of the family are interconnected with each other.

2. Parts of the family cannot be understood separately.

3. Family functioning cannot be understood by simply understanding one family member or part of the family. 
4. Family structure and organization are important factors that can influence and determine the behavior of family members.

5. Transactional patterns in the family system largely determine the behavior of family members.

Family functioning works well if the family can meet and maintain its members' biological, social, and psychological needs (Epstein et al., 1976). Based on this model, a healthy family functioning is a family that can still function (according to the six dimensions included in this model), although faced with needs to fulfill main tasks and overcomes family challenges. There are six dimensions of family functioning based on MMFF approach. The six dimensions will be explained in detail below.

1. Problem Solving, defined as family's ability to solve problems to the extent that they can function effectively (Epstein et al., 1978; Miller et al., 2000). Only unresolved problems faced by the family that may disrupt the family functioning. A family is categorized as healthy functioning if able to identify all of their problems and resolve it.

2. Communication, referred to how the process of information exchange takes place in the family (Miller et al., 2000; Epstein et al., 1978). A family who communicates with veiled and indirect messages is considered low functioning as the exchange of information that occurs tend to be ineffective.

3. Roles, defined as a pattern of activities carried out by the family to undergo its functions, such as daily routines, i.e., cooking, going on vacation, or schooling. A healthy functioning family is capable of equally dividing roles and have certain rules of conduct as an evaluation basis for role implementation process. The role accountability is the extent to which family members perform the roles for which they are responsible (Epstein et al., 1978; 2003).

4. Affective Responsiveness, defined as a family's ability to respond appropriately to the stimuli they receive (Epstein et al., 2003; Miller et al., 2000; Epstein et al., 1978). This affective response focuses on how family members can show emotions appropriately. For Epstein et al. (1978), a healthy functioning family is capable of displaying emotions according to the context of the situation in which the stimuli arise and are not glued by a single way of responding, as well as showing their emotions in normal levels. A wide range of emotions is also one of the characteristics of a healthy family function.

5. Affective Involvement, defined as a family as a unit exhibits an interest and appreciates the value of what the family members are interested in (Miller et al., 2000; Epstein et al., 1978). Affective involvement related to how and in what ways family members show interest and spend time with other family members. Healthy functioning families have a degree of empathetic involvement. This type of involvement is considered the best involvement, not too least or much.

6. Behavioral Control, defined as behavioral pattern adapted by the family to deal with several kinds of situations (Miller et al., 2000; Epstein et al., 1978). These situations are situations that are physically dangerous; situations related to meet psychobiological needs such as eating, drinking and sleeping; and situations related to socialization with others. If the family is functioning well, its members may learn and understand what behaviors are most appropriate to deal with these situations.

Based on the literature studies, we formulated two hypothesis, as followings: (1) gadget use has a negative effect on adolescents' family functioning, and: (2) there are significant differences of family functions' dimensions between adolescents with high and low risk gadget addiction, where adolescents with high risk of gadget addiction has lower family functioning dimensions.

\section{Methods}

Sample. This study used 226 adolescents (aged 1218 years old) who used gadgets and lived with their family. Participants were selected using the quota sampling technique, with $50 \%$ quota for each the high and low risk of gadget use addiction. 
Research Design. This research used a nonexperimental quantitative research design.

Instrument and Measurement. There are two instruments used. First is Smartphone Addiction Scale Short Version (SAS-SV) developed by Kwon et al. (2013) that has ten items. SAS-SV score is determined by the mean score. The resulting score can be categorized into two groups; low and high risk. These two groups were determined based on a cutting value, which is the participants' mean score. Researchers adapted this instrument and conducted item analyses. Reliability of 10 items from SAS-SV (using Cronbach Alpha) is 0.852 .

The second instrument is Family Assessment Device (FAD) by Epstein et al. (1983) to measure family functioning. Epstein et al. (2006, 2003) stated that FAD has a total score and scores for each of its dimensions. FAD had been translated into Bahasa by Mievela and Murti (2011). The reliability of each dimension of FAD ranged from 0.557 to 0.815 . Each dimension is assessed seperately because FAD is a multi dimensional construct. Originally, FAD has 60 items, but we only used 46 items in this research. Seven items were eliminated because the corrected value of total correlation is below 0.1 ( 3 items on communication, three items on roles and 1 item from behavior control dimension).

Data Analysis. The analysis technique used in this research is simple linear regression and one-way MANOVA to assess each dimensions of family functioning.

\section{Results}

Based on the results of simple linear regression calculations in table 1 , family functioning is predicted by gadget use. In other words, gadget use has a significant negative effect on family functioning, $F(1,224)=30.796, p<0.001$ (1-tailed). One point increase in gadget use will be followed by 0.646 point decrease in family functioning. In addition, there is a significant difference of family functioning's total score between participants with high and low gadget addiction risk gadget.
The $\mathrm{R}^{2}$ value indicates that there is $12.1 \%$ of the family functioning variance is affected by gadget use. According to the criteria proposed by Cohen (1988), this effect size is classified as medium-sized effect.

Table 1.

Regression Analysis (The effects of gadget addiction risk on family functioning)

\begin{tabular}{lcccccc}
\hline Variable & $\mathbf{F}$ & $\mathbf{B}$ & $\boldsymbol{S E B}$ & $\boldsymbol{\beta}$ & $\mathbf{t}$ & $\mathbf{R}^{2}$ \\
\hline $\begin{array}{l}\text { Addiction } \\
\text { (Gadget) }\end{array}$ & $30.796^{*}$ & -.638 & .115 & -.348 & -5.549 & .121 \\
\hline
\end{tabular}

\section{Notes.}

$\mathrm{B}=$ Beta Coefficient (Unstandardized); $S E \mathrm{~B}=$ Standard Error B; $\beta=$ Beta Coefficient (Standardized).

$* \mathrm{p}<.001$ (1-tailed). $\mathrm{df}=224$.

Based on MANOVA calculations, it is known that there are significant differences in family functioning based on addiction tendency level with $\mathrm{F}$ $(7,218)=4,852, \mathrm{p}<0,01$ (1-tailed); Wilks' $\Lambda=0.865$, partial $\eta^{2}=0.135$. These results indicate that there are significant differences on the seven dimensions of family functioning between the two groups of gadget use addiction (high and low risk). Based on Cohen (1988) also Miles and Shevlin (2001), the value of $\eta^{2}>0.14$ has a large effect size. Problemsolving dimension has the smallest difference between the groups.

Table 2

Differences in family functioning dimension in adolescents with high and low risks gadget addiction

\begin{tabular}{|c|c|c|c|c|}
\hline \multirow{3}{*}{$\begin{array}{c}\text { Family } \\
\text { Functioning }\end{array}$} & \multicolumn{4}{|c|}{ Addiction } \\
\hline & \multicolumn{2}{|c|}{$\begin{array}{c}\text { High Risk } \\
(\mathrm{n}=113)\end{array}$} & \multicolumn{2}{|c|}{$\begin{array}{c}\text { Low Risk } \\
(\mathrm{n}=113)\end{array}$} \\
\hline & $\mathbf{M}$ & SD & $\mathbf{M}$ & SD \\
\hline Total & 144.19 & 16.72 & 155.57 & 13.21 \\
\hline Problem Solving & 14.73 & 2.62 & 15.55 & 2.05 \\
\hline Communication & 8.64 & 1.93 & 9.33 & 1.54 \\
\hline Roles & 22.65 & 2.85 & 24.12 & 2.27 \\
\hline $\begin{array}{c}\text { Affective } \\
\text { Responsiveness }\end{array}$ & 17.12 & 3.10 & 19.04 & 2.64 \\
\hline $\begin{array}{c}\text { Affective } \\
\text { Involvement }\end{array}$ & 20.30 & 3.34 & 21.88 & 2.83 \\
\hline $\begin{array}{c}\text { Behavioral } \\
\text { Control }\end{array}$ & 24.09 & 3.27 & 25.87 & 3.12 \\
\hline General Dev. & 36.65 & 5.66 & 39.80 & 4.38 \\
\hline $\begin{array}{l}\text { Notes. } \\
* p<.01 \text { (1-tailed) }\end{array}$ & part & a sq & & \\
\hline
\end{tabular}


Table 3

Differences in family functioning dimension in adolescents with high and low risks gadget addiction

\begin{tabular}{cccc}
\hline Family & $\mathbf{F}$ & Sig $(\boldsymbol{p}) *$ & $\mathbf{\eta}^{\mathbf{2}}$ \\
Functioning & $(\mathbf{1 , 2 2 4})$ & & \\
\hline Total & 32.17 & .000 & .126 \\
Problem Solving & 6.62 & .006 & .029 \\
Communication & 8.80 & .002 & .038 \\
$\quad$ Roles & 18.38 & .000 & .076 \\
Affective & 24.86 & .000 & .100 \\
Responsiveness & & & \\
Affective & 14.66 & .000 & .061 \\
Involvement & & & \\
Behavioral & 17.50 & .000 & .072 \\
Control & & & \\
General Dev. & 21.79 & .000 & .089 \\
\hline Notes. & & \\
$* p<.01\left(1-\right.$ tailed). $\eta^{2}=$ & partial eta square. & \\
\hline
\end{tabular}

The effect size of partial $\eta^{2}$ of the differences in each dimension of family functioning is 0.029 ; $0.038 ; 0.076 ; 0.100 ; 0.061 ; 0.072 ; 0.089$; and for a total of 0.126. Based on the classification of effect size value by Cohen (1988) and Miles and Shevlin (2001). it can be concluded that gadget use has a medium effect on all dimensions in MMFF

\section{Discussion \& Conclusion}

Discussion. Previous studies on gadgets and family functioning had mixed results, where several studies have found both positive (Zhong, 2013: Bacigalupi \& Lambe, 2011; Lanigan, 2009) and negative relationships between gadget use and family functioning (Mesch, 2003; Villegas, 2013; Huisman et al., 2014; Drago, 2015). This study showed that gadget addiction risk negatively affects family functioning. This finding is also supported by Mesch (2003). He found that both types of activity and excessive use of gadgets had a negative impact on family functioning (Carvalho et al., 2014). As the addiction risk includes the tendency of excessive use, difficulty to control, and interference with daily activities (Kwan \& Leung, 2015, Kwon et al., 2013), gadget use can disrupt family functioning. Previous studies might have mixed results, as they did not study specifically on the excessiveness of gadget use in everyday life.

Furthermore, the results showed that there are differences in each dimension of family functioning between the high and low-risk groups. Dimensions highly affected by gadget addiction risk are the role, affective responses, affective involvement, and behavior control.

These four dimensions have a direct relationship with gadgets in the family. Hertlein (2012) explained that the role of environment (ecological influences) could promote changes in the structure and processes of family. The changes in structure and process may influence each other and play a role in environmental change. The presence of gadgets (environmental influences) leads to a change of family dynamics because it can alter family structures such as rules and role changes, as well as processes that occur in families such as affective affinity and communication (Hertlein, 2012).

In the context of adolescents' gadget use, the presence of gadgets brings changes in patterns of behavior and interaction within the family. It is because teenagers are more than happy to spend time in front of their gadgets, as it allows them to interact with people outdoors in their home, while doing other chores. If parents want their family to function properly even in the presence of gadgets, there need to be rules and changes in roles that are created. For example, limiting the time of gadget use and for what purpose while at home. Parents also need to adjust the role that exists in the family such as the division of tasks to not overly limit the teenager or let the teenager use his gadget all the time. If parents can make changes to the family structure to adapt to environmental changes (in this case the presence of gadgets), family members can still interact and spend more time together despite the presence or absence of gadgets in the family. Parents can set up a time when its good to use gadgets as not to interfere with the interaction between family members at home.

Unfortunately, gadget addiction can also occur because parents have difficulty in controlling the 
presence of gadgets and so, the teenagers use it excessively (Smahelova, Juhova, Cermak, \& Smahel, 2017). Lack of parental control poses a risk of weakening family functioning, seen as reduced family interactions because of the less time spent together in family. Another negative effect of lack of parental control is an uneven distribution of roles and reduced proximity in the family (Carvalho et al., 2014; Hertlein, 2012). This is related to the pattern of care and rules that apply to the family. Therefore, research related to the influence of parenting control on gadget addiction is needed.

The effect of gadget addiction is smaller on problem-solving dimension compared to others. We suspect that gadget use in adolescents is not directly related to problem-solving. Based on Tallman's findings (in Rueter, 1991), positive problem-solving can occur when family communications are good, there is a presence of authority in the family, and if all family members agree on their roles within the family. The gadget use may also improve problemsolving because gadgets can be a helpful medium, such as a monitoring device to ensure children's safety (Devitt \& Roker, 2009; Rueter, 1991). For example, through the use of gadgets, parents can be more relaxed when their teenagers are outside, because they can make sure whether their children are safe (Devitt \& Roker, 2009).

Furthermore, we suspect that the differences in problem-solving dimension tend to be lower because adolescents may not perceive problems in the family the same way. Referring to Epstein et al. (2003; 1978), the most important problem to solve is the instrumental problems of household expenditure, financial issues, and employment-related decisions. In fact, instrumental problems are mostly solved by parents and there are many parents who have not involve their teenagers in various problem-solving processes. Therefore, teenagers perceive almost no instrumental problems in the family that needed their attention or may even be unaware of related problems that exist.

Another reason is teenagers do not see excessive gadget use as a problem. This is related to the characteristics of gadget addiction mentioned by
Young and de Abreu (2001; Griffiths, 1996; \& Goodman,1990) that individuals often do not admit to having problems, even though the individual feels its negative impact on their behavior and later family functioning.

Conclusions. Gadget addiction negatively affects adolescents' family functioning, where higher gadget addiction risk leads to worse family functioning. Gadget addiction also has a big influence on all dimensions of family functioning. The greatest influence is found in role, affective responses, affective involvement, and behavioral control dimensions and the least is on problemsolving dimension.

\section{References}

Al-Barashdi, H. S., Bouazza, A. \& Jabur, N. H. (2014). Smartphone addiction among university undergraduates: A literature review. Journal of Scientific Research and Reports, 4, 210-225. doi: 10.9734/JSRR/2015/12245

Bacigalupi, G., \& Lambe, S. (2011). Virtualizing intimacy: Information communication technologies and transnational families in therapy. Family Process, 50, 12-26. doi: 10.1111/j.1545-5300.2010.01343.x

Carvalho, J., Francisco, R. \& Relvas, A. P. (2014). Family functioning and information and technologies: How do they relate? A literature review. Computers in Human Behavior, 45, 99-108. doi: 10.1016/j.chb.2014.11.037

Cohen, J. (1988), Statistical Power Analysis for the Behavioral Sciences, $2^{\text {nd }}$ Edition. Hillsdale, N.J.: Lawrence Erlbaum.

Dai, L. T. \& Wang, L. N. (2015) Review of Family Functioning. Open Journal of Social Sciences, 3, 134141. doi: 10.4236/jss.2015.312014

Devitt, K., \& Roker, D. (2009). The role of mobile phones in family communication. Children \& Society, 23, 189202. doi: 10.1111/j.10990860.2008.00166.x.

Drago, E. (2015). The effect of technology on face-to-face communication. The Elon Journal of Undergraduate Research in Communication, 6, 13-19.

Engs, R.C. (1987). Alcohol and Other Drugs: Self Responsibility. Bloomington, IN: Tichenor Publishing Company.

Epstein, N. B., Baldwin, L., \& Bishop, D. S. (1983). The McMaster family assessment device. Journal of Marital and Family Therapy, 9, 171-180.

Epstein, N. B., Bishop, D. S., \& Levin, S. (1978). The McMaster model of family functioning. Journal of Marriage and Family Counseling, 4, 19-31.

Epstein, N. B., Ryan, C. E., Bishop, D. S., Miller, I. W., \& Keitner, G. I. (2003). The McMaster model: A view of healthy family functioning. In Froma Walsh (Ed.), 
Normal family processes: Growing diversity and complexity (pp. 581-607). New York: The Guilford Press.

Geser, H. (2006). Are girls (even) more addicted? Some gender patterns of cell phone usage. Sociology in Switzerland: Sociology of the Mobile Phone. Retrieved from http://socio.ch/mobile/t_geser3.pdf

Goodman A. (1990). Addiction: definition and implications. British Journal of Addiction, 85,140314088.

Griffiths M. (1996). Behavioral addiction: An issue for everybody?. The Journal of Workplace Learning, 8, 1925. doi: 10.1108/13665620610116872

GSM Association. (2013). Children's use of mobile phones. Retrieved from https://www.gsma.com/publicpolicy/wpcontent/uploads/2012/03/GSMA_ChildrensMobilePhon es2012WEB.pdf

Hertlein, K. M. (2012). Digital dwelling: Technology in couple and family relationship. Family Relations, 61, 374-387. doi: 10.1111/j.1741-3729.2012.00702.x

Kwan, H. C. \& Leung, M. T. (2015). The Path Model of Parenting Style, Attachment Style, Self-Regulation and Smartphone Addiction. In Jane M. Montague \& Lee Ming Tan (Ed.), Applied Psychology Proceedings of the 2015 Asian Congress of Applied Psychology (ACAP 2015) (pp. 108-131). Singapore: World Scientific Publishing Company.

Kwon, M., Kim, D. J., Cho, H., \& Yang, S. (2013). The smartphone addiction scale: Development and validation of a short version for adolescents. PLOSone, 8, 1-7. doi: 10.1371/journal.pone. 0083558

Lamanna, M. A. \& Riedmann, A. (2005). Marriages \& families: Making choices and facing change. Boston, MA: Wadsworth Publishing Co.

Lanigan, J. D. (2009). A sociotechnological model for family research and intervention: How information and communication technologies affect family life. Marriage \& Family Review, 45, 587-609. doi: 10.1080/01494920903224194

Lin, Y., Chiang, C.L., Lin, P. H., Chang, L. R., Ko, C. H., Lee, Y. H., Lin, S. H. (2016). Proposed diagnostic criteria for smartphone addiction. PloS One, 11. doi: 10.1371/journal.pone. 0163010

May, T. K. (2013). TED radio hour asks: "Do we need humans?". Retrieved from http://blog.ted.com/tedradio-hour-asks-do-we-need-humans

Mesch, G. S. (2003). The family and the internet: The Israeli case. Social Science Quarterly, 84, 1038-1050. doi: 10.1046/j.0038-4941.2003.08404016.x

Miles, J. N. V. and Shevlin, M. E. (2001). Applying regression and correlation: a guide for students and researchers. London: Sage Publications.

Miller, P. H. (2011). Theories of Developmental Psychology (5th ed.). New York: Worth Publishers.

Miller, I. W., Ryan, C. E., Keitner, G. I., Bishop, D. S., \& Epstein, N. B. (2000). Journal of Family Therapy, 22, 168-189.
Milward Brown. (2014). AdReaction: Marketing in multiscreen world. Retrieved from https://www.millwardbrown.com/adreaction/2014/repor t/Millward-Brown_AdReaction-2014_Global.pdf

Moeller, S., Chong, E., Golitsinski, S., Guo, J., McCaffrey, R., Nynka, A., \& Roberts, J. (2010). A day without media. International Center for Media and the Public Agenda. Retrieved from http://withoutmedia.wordpress.com

Nielsen Company. (2011). The digital media habits and attitudes of southeast asian consumers. Retrieved from $\mathrm{http} / / / \mathrm{www}$.grahamhills.com/wpcontent/uploads/2011/11/71370794-The-digital-mediaand-habits-attitudes-of-South-East-Asian-

Consumers.pdf

Papalia, D.E. \& Martorell, G. (2014). Experience Human Development (13th International ed.). New York: McGraw-Hill.

Peele S. \& Brodsky A. (1979). Love and Addiction. New York: Taplinger.

Pew Research Centre. (2015). Teens, social media \& technology overview 2015. Retrieved from http://www.pewinternet.org/2015/04/09/teens-socialmedia-technology-2015/

Pezullo, L., Taylor, P., Mitchell, S., Pejoski, L., Le, K., \& Bilgrami, A. (2010). Positive family functioning. From Australia Government Database.

Rosen, L. D., Lim, A. F., Felt, J., Carrier, L. M., Cheever, N. A., Lara-Ruiz, J. M., Mendoza, J. S. \& Rokkum, J. (2014). Media and technology use predicts ill-being among children, preteens and teenagers independent of the negative health impacts of exercise and eating habits. Computers in Human Behavior, 35, 364-375. doi: 10.1016/j.chb.2014.01.036

Rothman, D. (n.d.). A tsunami of learners called generation $\mathrm{Z}$. Retrieved by http://mdle.net/Journal/A_Tsunami_of_Learners_Called _Generation_Z.pdf

Rueter, M.A. (1991). An organizational model of family problem solving interaction. Retrospective Theses and Dissertations. Paper 10065.

Sihombing, R.A. (2018). Kecanduan Smartphone, 2 Pelajar di Bondowoso Alami Gangguan Jiwa. Liputan 6.

Retrieved from http://news.liputan6.com/read/3230086/kecanduansmartphone-2-pelajar-di-bondowoso-alami-gangguanjiwa

Smahelova, M., Juhová, D., Cermak, I., \& Smahel, D. (2017). Mediation of young children's digital technology use: The parents' perspective. Cyberpsychology: Journal of Psychosocial Research on Cyberspace, 11(3), article 4. http://dx.doi.org/10.5817/CP2017-3-4

Srivastava, L. (2005). Mobile phones and evolution of social behavior. Behavior and Information Technology, 24, 111-29.

Törocsik, M. Szucs, K. \& Kehl, D. (2014). How generations think: Research on generation Z. Acta Universitatis Sapientiae Communicatio, 1, 23-45. 
Valkenburg, P. M. \& Soeters, K. E. (2016). Children's positive and negative experience with the internet: An exploratory study. Communication Research, 28, 652675.

Villegas, A. (2013). The influence of technology on family dynamics. Proceedings of the New York State Communication Association, 2012 [Article 10]. Retrieved from http://docs.rwu.edu/nyscaproceedings/vol2012/iss 1/10

Wei, R. \& Lo, V. H. (2006). Staying connected while on the move: Cell phone use and social connectedness. New Media \& Society, 8, 53-72. Doi:

$10.1177 / 1461444806059870$
West, R. \& Brown, J. (2013). Theory of Addiction (2nd ed.). Singapore: Wiley-Blackwell.

Young, K.S. \& de Abreu, C.N. (2011). Internet addiction. Canada: John Wiley \& Sons.

Zhong, B. (2013). From smartphones to iPad: Power users' disposition toward mobile media devices. Computers in Human Behavior, 29, 1742-1748. doi: 10.1016/j.chb.2013.02.016 